TASTING DIFFERENCE 



\section{TASTING DIFFERENCE}

Food, Race, and Cultural Encounters in Early Modern Literature

GITANJALI G. SHAHAN I 
Copyright (C) 2020 by Cornell University

All rights reserved. Except for brief quotations in a review, this book, or parts thereof, must not be reproduced in any form without permission in writing from the publisher. For information, address Cornell University Press, Sage House, 512 East State Street, Ithaca, New York 14850. Visit our website at cornellpress.cornell.edu.

First published 2020 by Cornell University Press

Library of Congress Cataloging-in-Publication Data

Names: Shahani, Gitanjali, author.

Title: Tasting difference : food, race, and cultural encounters in early modern literature / Gitanjali G. Shahani.

Description: Ithaca : Cornell University Press, 2020. Includes bibliographical references and index.

Identifiers: LCCN 2019026547 (print) | LCCN 2019026548 (ebook) | ISBN 9781501748707 (hardcover) | ISBN 9781501748714 (epub) | ISBN 9781501748721 (pdf)

Subjects: LCSH: English literature-Early modern, 1500-1700-History and criticism. | Food in literature. | Food habits in literature. | Race in literature. | Race relations in literature. | Cultural relations in literature. | Colonies in literature.

Classification: LCC PR428.F66 S53 2020 (print) |

LCC PR428.F66 (ebook) | DDC 820.9/356409031—dc23

LC record available at https: / / lccn.loc.gov/ 2019026547

LC ebook record available at https: / /ccn.loc. gov $/ 2019026548$ 
For Rohit and Arihaan 
